Higher Education Quarterly

\title{
What's In A Name? The Impact of Reputation and Rankings on the Teaching Income of English Universities
}

\begin{tabular}{|r|l|}
\hline Journal: & Higher Education Quarterly \\
\hline Manuscript ID & HEQU-Jul-17-0072.R2 \\
\hline Manuscript Type: & Article \\
\hline Keywords: & University fees, income, reputation, brand, rankings \\
\hline \multicolumn{3}{c}{} \\
\multicolumn{3}{c}{$\begin{array}{c}\text { SCHOLARONE } \\
\text { Manuscripts }\end{array}$} \\
&
\end{tabular}


What's In A Name? The Impact of Reputation and Rankings on the Teaching Income of English Universities

\section{Introduction}

In today's global and knowledge-based economy, universities play an ever greater role both in determining individuals' labour market success and in generating research than ever before. Tertiary enrolments have soared across all continents; moreover, very large number of students now study outside their countries of origin. Universities now operate in an environment characterised not just by globalisation itself but, as discussed below, by attendant changes in stratification systems and growing marketisation. (Altbach and Knight 2007; Marginson 2016)

Funding has changed accordingly. Historically, universities were funded through private fees and charitable donations. Later, many governments moved to direct funding of public higher education, with no or very low charges to students. Government grants remain central to university funding but for the last quarter-century, governments under budgetary pressure have sought to increase private contributions and have re-introduced or raised tuition fees.

Reputation and 'brand' are central to institutions' success in the resulting competitive environment. (Molesworth, Scullion and Nixon eds, 2011, Blackmore 2016). The muchdiscussed growth in university rankings has had a major impact on reputational dynamics; and scholars have argued that higher education is increasingly subject to 'winner-take-all' forces, in which a few reputational winners receive large benefits (Frank and Cook 1995; Wolf 2002; Marginson 2014; Fowles et al 2016). If so, we can expect that reputational winners may, inter alia, derive direct financial benefits through an ability to charge higher fees. This article contributes novel empirical evidence by examining the relationship between reputation and teaching income across an entire national system, England. We ask "Is a university's teaching 


\section{income directly affected by reputation?' and examine a number of reputational factors, including league tables. The findings have important policy implications.}

\section{Stratification and marketisation}

Stratification of universities at national level is not new. A university or college education is a source of concrete skills and knowledge, but it has always been a 'positional good' as well, enhancing individuals' position compared to that of others because it signals general qualities and also provides access to high-status networks. In many (though not all) national systems, there has been differential status attached to attendance at one university rather than another. In positional good terms, it can matter greatly which university someone attended, not merely whether they attended university. (Bourdieu 1998; Yudkevich, Altbach and Rumbley 2016). Recently, the university sector has become increasingly globalised, and Marginson argues that, as a result, a worldwide system of stratification has emerged with ever-growing effects at local and national levels. (Marginson 2016)).

The development of a highly stratified university system is strongly linked to the increased marketisation of higher education. Marketisation, meaning that market principles become increasingly important for both the supply and demand for higher education, is evident in many national systems. (Molesworth et al 2011) Developed countries such as the UK or Australia have altered governance and financing systems to do this without much private capital or ownership, creating 'quasi-markets'. Meanwhile, rapid growth of private institutions alongside public ones is evident in many middle-income and emerging economies (Bok 2003; Brown 2011).

Marketisation, by design and intent, means that universities find themselves in strongly competitive environments (Molesworth op cit). One visible effect has been the growth of 
dedicated marketing departments and strategies (Hemsley-Brown and Oplatka 2006). Another is the very strong preoccupation of contemporary universities, and their senior officers, with reputation. Management scholars see reputation as an 'intangible resource that enables competitive advantage' (Finch et al 2013: 35) and research confirms the importance of reputation in a marketised higher education sector (Bienkowski et al 2012).

\section{Reputation and brand}

An organisation's reputation is created by and through the judgement of others: it can thus be seen as a 'collective representation of....past actions' (Gardberg and Fombrun 2002). However, it is not necessarily ordinal: many or all organisations in a given category can have the same or similar reputations on particular measures, and reputations can exist at group level. Blackmore (op cit) distinguishes it from prestige, which is inherently relative and zero-sum, and documents the preoccupation of contemporary university leaders with both.

Scholars agree that reputation and prestige are critical in attracting many, and good, students and good faculty (Fumasoli \& Huisman 2013). Universities therefore strive to signal that they are highly desirable destinations. They may advertise their alignment with an 'institutional template' characteristic of high-status institutions (Pizarro Milian 2017); or highlight specific attributes and create a specific 'brand' (Chapleo et al 2017). Market positioning is now seen as centrally important in the not-for-profit sector, as it has long been in the private sector but there is little empirical research on impact as compared to communication strategies(Hemsley-Brown op cit).

One way for universities to signal their desirability is by their association with certain other universities. The US 'Ivy League' group of universities is technically no more than an athletics league, but has become a byword for excellence: it plausibly adds to the prestige of Dartmouth, if not of Harvard, to belong. In Canada, research has demonstrated that employers perceive higher education institutions from different categories as having quite distinct and 
shared characteristics, which, as the authors note, may be an asset for some, and bring higher prestige, but a liability for others (Finch et al 2013).

British universities have formed a number of very clear mission groups, which may also function as brands signalling common characteristics. Filippakou and Tapper (2015: 134) link this development to 'the desire of the universities to seek out more favourable branding images'. They also note that, among these groups, only the Russell Group, comprising large research universities with selective admissions, has proven highly attractive to would-be members . It is also the only one which is widely known outside the sector.

While reputational factors do not automatically generate individual hierarchies, scholars agree that reputation conveys competitive advantage and that position in any global higher status hierarchy, of the type identified by Marginson (2016) and Altbach (2004), will be closely linked to reputation (Finch op cit, Gardberg and Fombrun op cit). Moreover, the larger and more disparate the marketplace in which a university is recruiting, the harder it will be for potential students to draw on complex contextualised knowledge about an institution, and the more likely they will be to seek generalized, composite indicators. This will be true for national as opposed to local and regional contexts, and even more true in a international one. (Rosenzweig 2014; Hazelkorn 2015) The growing influence of global league-table rankings is, we would argue, to be understood in this context.

Country-specific rankings of universities (such as by US News and World Report in the USA) have existed in several countries for a good number of years. International 'league tables' such as those of Shanghai Jiao Tong University and Times Higher Education are quite recent (originating in 2003 and 2004, respectively) but have very quickly come to affect organisational behaviour (Marginson 2014; Yudkevich, op cit). Concern over rankings has made the collection and analysis of data of central concern to senior management teams (Morphew et al op cit; Hazelkorn 2015: 110) and affects internal resource allocation (Kim 2017). 
Evidence relating domestic rankings to student behaviour suggests differences by institutional type. Sauder and Lancaster (2006) examined the impact of the US News and World Report (UNSWR) annual law school rankings. Their analysis, using numerical rankings for top schools and a breakdown into four tiers overall, showed that, among higher-ranked schools, the number of applicants increased by a small but significant amount for every one-place increase in rank. They also note that tier membership changes rarely. Luca and Smith (2013) report similar results for 'top 25' and 'top 50' USNWR institutions. In the UK, Gibbons et al (2015) investigated the impact on applications of published 'National Student Survey' rankings. They find that changes have small, though statistically significant, effects on application rates, concentrated among more highly qualified students and heavily oversubscribed institutions. Conversely, among American "Historically Black Colleges and Universities", which typically have quite low academic entry standards, domestic rankings appear to have no significant effect on admissions (Jones 2016).

In contrast, Hazelkorn found that an overwhelming majority of international students use rankings to inform decisions with high-achieving and affluent students especially likely to use them. (Hazelkorn 2015 passim). Bastedo and Bowman (2010) looked at the impact of domestic rankings on financial outcomes, using a sample of 225 US universities that appear in the composite U.S. News rankings. They analyse tuition and fees for in-state and out-of-state students separately, since the latter are routinely set at much higher levels. Domestic (US) rankings had a significant effect on out-of-state income 2 or 4 years later, but not on in-state. This is consistent with our suggestion that composite rankings may be especially important when recruitment is over a wide area.

In international rankings, research indicators and citations dominate outcomes (Kaycheng 2015). This makes research reputation critical to creating a virtuous circle in which more research funding generates good research outcomes, and enhances desirability further. 
(Morphew, Fumasoli and Stensaker 2017). If reputational winners also derive direct financial benefits through an ability to charge higher fees, or attract more students, this makes sustained research excellence more affordable and can explain the observed stability of US rankings (Fowles 2016, Sauder and Lancaster op cit).

The vice-chancellor of New Zealand's top-ranked university considers it self-evident that 'of course...income per student ...is correlated with international rankings' (McCutcheon 2017). We hypothesise that he is correct and indeed that the impact of reputation on institutions' teaching income will be large and clearly observable. We study this question across an entire national system, for what we believe to be the first time, using comprehensive data from England. We focus on teaching income, made up of both fees and recurrent payments for teaching from government: teaching income is a clearly identified income stream in our data set. We make use of a number of reputational variables, and so can also address the question of whether international rankings are as important as many observers believe.

\section{Higher education in contemporary England}

The English university sector is well suited to this research. First, comprehensive income and administrative data are available from the early 2000s. Second, the sector is sizeable, making it feasible to estimate the quantitative impact of different variables. Third, as discussed below, student fees make up a very large part of teaching income, and universities have considerable freedom to set their own fee levels for some (though not all) courses. In principle, therefore, teaching income per student may vary considerably. Not all these features are shared across the increasingly devolved UK: Scotland, Wales and Northern Ireland have developed quite distinct funding regimes. Indeed simply being a university in England, rather than Scotland, Wales or Northern Ireland, now has a highly significant positive effect on teachingincome per student (Jenkins and Wolf 2016). Our analysis therefore concentrates on England. 
Teaching income Universities in England receive money for teaching purposes from a combination of sources. For home undergraduates (which includes all who are EU domiciled), degree study remained free at the point of use until the late 1990s (Aldrich 2002). Governments paid fees and teaching grants, at levels related to subject of study, and controlled the number of students per university. In the 1990s, rapid expansion was secured by reducing spending per home student, and quality declined (Palfreyman and Tapper 2014). Fees paid directly by the students were therefore introduced by the 1997 Labour government, albeit initially at a very low level, with the bulk of undergraduate teaching income continuing to come from the government. From 2006, a system of higher fees was implemented, alongside some continuing government payments for teaching, notably for high-cost science, engineering and technology subjects. Home (EU) students can borrow their fee payments through the government's Student Loans Company and then repay, as and when they earn enough. The government sets maximum levels (fee caps) for undergraduate home students, and universities could in principle charge less than the cap. However, there is little incentive to do so (Wolf 2016) and home undergraduate fees are effectively uniform for English universities.

This is not true for any other group of fees. Postgraduate fees for home students have been progressively deregulated, and are mostly set by individual institutions. Moreover, universities have, since the early 1980s, been able to recruit as many 'international' (non EU) students as they wish at all levels (subject to the students' academic competence), and also decide what to charge them. This has led to a rapid increase in international students and international fee income. By 2007-8, 16\% of overall teaching and tuition revenue in England derived from international (non-EU) students (Dearden et al 2012). By 2013/14 this had risen to $24 \%$. (HESA )

The analyses reported here focus on teaching income per student in the period up to and including 2013-14 because, immediately afterwards, further major changes were made whose 
disruptive effects are not yet clear. Total home student numbers were traditionally tightly controlled at institutional level. These caps were, quite unexpectedly, abolished in 2014. In the short period since, there have been major swings in home recruitment, with some universities expanding very fast and others shrinking. To obtain quantitative estimates of reputational impact on income, we needed to study a period of relative stability where we could identify and control for other variables, and 2013-14 marks the end of such a period.

Sector characteristics England's higher education sector is very homogeneous in its institutional structure (Moodie 2015). Almost all institutions are universities which grant all levels of degree (bachelors, masters, doctoral) and are subject to the same funding and regulatory regimes including intensive periodic reviews by government of research quality. The results of these reviews are public, and are important in establishing the research reputation of institutions and individual faculties. This organisational homogeneity is relatively recent. It follows from the 1992 decision to transform all polytechnics into universities; and the progressive transformation, thereafter, of other existing higher education institutions, including colleges of higher education and specialist institutions (conservatories, art colleges, agriculturat eolleges) into universities with full degree-awarding powers.

English higher education is also, in reputational terms, extremely heterogeneous. This has been true for many decades but the institutional changes described above have further increased heterogeneity on variables associated with reputation and prestige. (Palfreyman op cit). England is second only to the United States in the number of its universities which rank high in global tables; but has many which do not appear by name in any rankings. This combination of organisational homogeneity and reputational heterogeneity is important in making this analysis possible.

\section{Sample, variables and method}


The study focuses on (a) generalist universities which (b) faced the same strategic opportunities and limitations as the large majority of the sector during the period 2007-14. To create the sample we determined that institutions should be eligible for Student Loans Company funding; not exclusively postgraduate; and sizeable - so having at least 1,000 undergraduates, at least $75 \%$ of them doing full degrees, and at least $60 \%$ studying full-time. These criteria excluded a few unusual institutions (eg the Open University, which educates part-time distance learners). We excluded specialist institutions (eg conservatoires) which do not meet the criteria for inclusion in established ranking exercises (national and/or global). 97 English universities met the criteria for inclusion and are listed in Table A1, along with their university 'type' or mission group. However, one university, Buckingham, is a private university which does not belong to any of the groups, and since most of our models include group membership as a variable, it is excluded, leaving a maximum sample of 96 for analysis. Institutional size varies enormously within this group, and teaching income-per-student, not total teaching income, is therefore the preferable outcome measure.

Teaching income per student varies markedly among English universities and has done for a good number of years. This is shown in Figure 1, for both 2007-8 and 2013-14. 2007-8 was chosen as a comparator because it was just before publication of the results of research quality review carried out by the UK government. These reviews, as noted above, occur only periodically, may affect reputation, but have no direct impact on teaching income. The 2008 results (from the Research Assessment Exercise (RAE)) were not superseded until after the 2014 Research Excellence Framework (REF) review: another reason for using 2013-14 as a cutoff.

[FIGURE 1 HERE] 


\section{Explanatory variables}

While the focus of the study is the impact of reputation on teaching income, it was important also to identify, and control for, other factors. We hypothesise that the following nonreputational characteristics of a university might affect levels of teaching income per student:

Academic composition of the student body. Significant financial support is still received directly from government for high-cost degrees, so the proportion of such degrees will affect teaching income per student.

Internationalisation of the student body The average level of teaching income received per non-EU student is well above the average teaching income per EU (home) student. (Dearden et al 2012: 85) Institutions that have higher proportions of international students may therefore have higher per-student teaching income.

Location Some locations may be more or less attractive to high-fee students because of housing or labour market factors.

Rate of growth of the university. Institutions with high overall levels of demand may opt to increase overall size as a way of increasing the proportion of high-fee students in popular courses without having to close less popular ones.

Size Larger institutions (with larger enrolments) may find it easier to respond quickly and effectively to changes in student demand and government policy.

Undergraduate/postgraduate mix England's home undergraduate fees are highly regulated, but most postgraduate fees are not. Institutions which have made a strategic decision to increase the proportion of postgraduates may have higher per-student teaching income.

In addition, a number of actual or potential reputational variables can be identified. 
Global reputation rankings A number of global league tables have become highly important in framing university behaviours, as discussed above. One of the best-known is the Times Higher Education (THE). It uses a wider set of criteria than the Jiao Tong or QS rankings (also frequently cited), and is used for the analyses.

UK-specific league tables In the UK the best known is from The Guardian newspaper. It weighs non-research indicators heavily and its rankings diverge from those of research-heavy league tables.

University type or brand Reputation may be affected by the 'brand' of the national system overall or by the within-nation category to which an institution belongs. As discussed above, one response to the reputational heterogeneity of British universities has been the formation of mission groups, with 24 of the large research-intensive universities organised as the 'Russell Group'. In addition, a distinction is often drawn, within and outside the sector, between 'pre-92' and 'new' or 'post-92' universities. This does not relate to the overall age of an institution, but to when it became a full university: and 1992 was when a large number of polytechnics all became full universities at the same time. Figure 2 shows almost no overlap at all between Russell Group and post-92 institutions in teaching income per-student, although of course, this is not necessarily a direct result of group membership, but indicates how wide differences now are. Figure 2 also shows the strong growth in teaching income per head enjoyed by the English university system overall during the period under study, driven by increased home undergraduate fees, and rising international enrolments .

[FIGURE 2 HERE]

Government research rankings The UK government, as already noted. operates a system of periodic research quality assessments, whose results are widely disseminated. Rankings are 
subject-specific, and so allow individual faculties or small specialised institutions to obtain a high overall rank. They are also likely to be strongly associated with league table rankings (Keycheng op cit).

Measures of student satisfaction The English government has since 2004 run a National Student Survey which asks final-year undergraduate students to rate their experiences. The results are publicly available.

\section{$\underline{\text { Data }}$}

Income data were obtained via HEIDI, the Higher Education Information Database for Institutions, which is the web-based management information service for the UK's Higher Education Statistics Agency (HESA). Teaching income per student was constructed by dividing teaching income by the number of FTE students in the same year.

As for explanatory predictors, a number of derived variables were created including the proportion of non-EU international students and of postgraduate students in total FTE student numbers, and growth of overall student numbers, undergraduate numbers and postgraduate numbers from 2007 to 2014. Another variable measured the proportion of students on high cost 'STEM-related' (i.e. Science, Technology, Engineering and Mathematics) which attract additional teaching grants. Binary variables were created for the presence of a medical school, and for whether the university is in the Greater London area. A categorical variable distinguished between Russell Group, other pre-92 universities, and post-92 universities. On research, we used results of the government's 2008 'Research Assessment Exercise' (RAE) aggregated to university level, with a ranking based on grade-point average. From the National Student Survey (NSS) we used the percentage who 'definitely' or 'mostly' agreed that 'Overall, I am satisfied with the quality of my course'. 
Method

The method used in this paper is multiple linear regression analysis. This enables the researcher to control for a range of variables when examining the key relationship of interest: in this case, between measures of reputation and teaching income. Descriptive statistics and bivariate correlations were used to explore the relationships between the variables in our dataset and make informed decisions on whether or not to retain all variables. This confirmed the strong relationship between most reputational indicators and teaching income (the exception being the NSS: $r=0.39$ ).

An assumption underlying basic forms of linear regression analysis is that the variance of the residuals is constant across all observation points. However, our data display signs of being heteroskedastic - there is increasing variance with a number of the explanatory variables as Figure 3 illustrates. We have therefore adopted the widely used technique for estimating robust standard errors that does not require a constant variance assumption (Kaufman 2013). This typically yields larger standard errors, and so makes it less likely that statistically significant results will be obtained than under standard linear regression assumptions.

\section{FIGURE 3 HERE}

The regression analysis started with models containing few explanatory variables, and added further variables in stages. The modelling process was sequential, dropping variables which were not statistically significant at each stage. A number of different approaches were used. The first set of models looked at how far a number of explanatory variables are able to predict teaching income per student. The second set took growth in teaching income per student as the outcome variable. If successful institutions enter a 'virtuous circle', in which outputs and 
reputation are self-reinforcing, then over time (ceteris paribus) they are likely to exhibit faster growth and not just higher levels of teaching income per student. Finally, a more explicitly longitudinal approach, utilising panel regression techniques was used to examine directly whether changes in reputational variables were associated with changes in teaching income. The results of all three approaches are reported in the next section, although it should be emphasised that, because of data limitations, the results of the second and third approaches must be treated with caution.

\section{Results}

Table 1 reports a first set of regression results. These examine the predictive power of a number of 'domestic' variables, using two UK-specific reputational variables, combined with measures of student mix and subject mix. Models 1 and 2 explore the predictive power of the reputational variables, and models 3, 4 and 5 examine how far this is reduced (and may therefore be accounted for) by other institutional characteristics.

Table 1 here

The reputational variables are how highly ranked the university was in the 2008 government research ratings ('RAE rank'), and university type, where the reference category is 'other pre-92' universities, i.e. those older institutions which are not in the Russell Group. Neither is directly linked to teaching income in any way: any effect must therefore be through fee levels. Three universities have no RAE data and are omitted from these analyses. Model 1 shows a strong relationship between RAE ranking and teaching income per student: note that the top rank is 1 , so this appears as a negative number. Moving from, for example, $5^{\text {th }}$ to 4 th, or from $26^{\text {th }}$ to $25^{\text {th }}$ place is associated with a $£ 36$ rise, and being in the top third rather than the bottom third of the overall RAE rankings is associated with about a $£ 3,000$ rise in teaching 
income per student . In model 2, being a Russell Group university is associated with almost $£ 1700$ extra teaching income per-student compared to other 'old' universities (equivalent to rising over 40 places when RAE alone was used.) [1] The $\mathrm{R}^{2}$ in the model 2 regression is 0.65 , suggesting that $65 \%$ of the variation can be accounted for using just two reputational factors.

The remaining models in Table 1 add London location, university size, the proportion of STEM students (because home undergraduates in these subjects attract higher average teaching income) and the proportion of international (non-EU) students to the regression analysis. The proportion of international students was highly significant $(\mathrm{p}<0.001)$ as expected but in the full model (model 5) proportion of STEM students is significant only at the 5\% level . Being in London was strongly and positively associated with teaching income per student even after controlling for other factors. Other things equal, universities in London had over $£ 800$ per student more teaching income after allowing for other variables in the regression model. The size of the university was significantly associated with teaching income per student although the predicted substantive impact was small to moderate. Having a medical school, and university growth, were dropped at this point as non-significant. [2]

As other variables were introduced, the effect size of the research reputation (RAE) variable became progressively smaller and in Models 4 and 5 it is no longer statistically significant. That is, one can no longer reject the null hypothesis of no association between teaching income per student in 2013/14 and RAE 2008 ranking. Being a member of the research-intensive Russell Group, however, remains extremely important.

Table 2 again focuses on domestic variables: National Student Survey scores and the Guardian newspaper's UK-only league table (which emphasises non-research variables.) Four universities lack Guardian rankings and are omitted. Each of these reputational variables was significantly associated with teaching income per student when no controls were used (models 1 and 3), although the effect sizes were small. However, both are insignificant once we control for 
other factors which may influence teaching income per student. Being a research-intensive Russell Group member and being in London again have a very large effect. $\mathrm{R}^{2}$ for the final model here is almost exactly the same as in the final model in Table $1\left(\mathrm{R}^{2}=0.853\right)$ : in other words, adding in the NSS or Guardian scores does not increase explanatory power.

Table 2 here

Table 3 shows the association between global rankings and teaching income per student, using THE world rankings. These rankings, though very well known, impose some serious limitations on the analysis. Over the 2007-14 analysis period, they give an individual rank only to the top 200 institutions, with other listed institutions being placed in groups or tiers. [3] 26 English institutions appear in the top 200. This is an extremely small sample although analysis results for this sub-group (using a scale variable for individual rank) are consistent with, while predictably weaker, than for the whole sample. Table 3 therefore uses category variables for rankings and includes the full data set.

Table 3 here

In the absence of any other explanatory variables, being an English university in the top 50 of the THE rankings is associated with approximately $£ 5,700$ extra teaching income per student. Being ranked between 51 and 200 is also significant and worth nearly $£ 2,200$ per student. Adding further explanatory variables reduces the effect size and significance of the international ranking variable but it remains large - $£ 2,700$ per student- for those in the top 50 . University type also continues, in these models, to be associated with teaching income levels, Overall, $\mathrm{R}^{2}$ is high (=0.896).

Overall, some but not all reputational variables appear very strongly related to teaching income. Global rankings and Russell Group membership, both highly research-related, appear to have the strongest influence, and are highly correlated: virtually all Russell Group universities are in the THE top 200. [4] Other domestic rankings do not appear to be important. 
While consistent with the hypothesis that reputation translates into income, these are cross-sectional results. They do not examine whether gaps tend to widen over time between higher and lower reputation institutions, or whether changes in reputation have an impact (as will occur if the link is direct). Further analyses therefore looked at growth in teaching income per student between 2007/8 and 2013/14.

Table 4 here

Table 4 uses a number of explanatory variables that were statistically significant in models reported above. Only 25 institutions had individual ranks in the THE rankings across the period, and, not surprisingly, there were generally no significant results for this very small sample. Table 4 provides results for the full sample and employs a variable that (using the same categories as in Table 3) records whether or not there was a change in a university's THE category (tier). Results must be interpreted with caution, because there were major changes to the ranking system after 2009 so that the end of the period is not strictly comparable to the start. Moreover, only a few universities changed category (as one might predict if reputation tends to be self-reinforcing). Nonetheless, the results indicate that upward change for an institution is positively related to teaching income growth. So is university type, with new universities showing significantly less growth.

As noted above, pooling several years of data and applying panel regression techniques allows one to examine changes over time (an approach used by, for example, Sauder and Lancaster op cit). An advantage of these techniques is that we can include fixed effects for institution, and so control for effects that are unobserved (Allison 2009). The disadvantage is that, in panel models, change in the variables is required in order to provide estimates - any variables which do not change over time will drop out. In the key case of global rankings, data limitations are serious: we can only obtain estimates if institutions change their 'value' on this variable and only a very small number of universities have individual integer ranking. Using 
categorical rankings, to overcome sample size issues means very little change, because, as already noted, few move categories in any one year or even over the whole period.

Table 5 here

Table 5 shows results for 2007-14. This was, as shown above, a period of rapid though uneven increase in teaching income across the sector (as indicated by the year dummies). These analyses use five categories for the Times Higher ranking which can be applied across the period: the top 200 are split into groups of 50 and the fifth is any outside the top 200 . This has the advantage of being a little closer to the integer rankings we would ideally like to use but the disadvantage of having rather smaller numbers within each of the top four categories, plus a large number of cases who are simply 'outside the top 200'. Nonetheless, we obtain quite large effect sizes for the post 2009 years. For example, the effect of being ranked in the top 50, according to model (2), Table 5, is about $£ 850[=£ 48.43+£ 800.86]$ extra income per student. However, there is no statistically significant effect of being in the top 50 in the years prior to 2010 (note the interaction term is coded 0 for 2009 and earlier), while some of the other rankings are significantly negative for this pre-2010 period. The crude interaction term is, arguably, doing something to capture the effects of the structural break in the time series when THE ranking criteria changed in 2010.

Overall, these different approaches all indicate that some reputational variables are positively associated with English universities' teaching income per student, as hypothesised, and that their impact on teaching income is substantial. The measures which are consistently significant are those which are generic, easily available and easily understood, including to international markets: global THE rankings appear to be especially important, in contrast to domestic reputational measures. The power of some reputational variables to predict differences 
in average teaching income per student dwarfs that of other factors such as subject mix, or proportion of overseas students.

\section{Conclusion}

These results provide, for the first time, clear evidence of how very well reputation may 'pay', in the context of a globalised and marketised university system. They also provide insights into the central importance of research. Global rankings are overwhelmingly based on research, while the 'Russell Group' brand is also largely research-based. Hence, universities with strong research are well placed to earn significantly higher teaching incomes, attract good faculty and students, and produce good outcomes (both research and teaching-related) which reinforce their reputation. The system thus tends to produce a very stable status hierarchy at global level, and in the rankings which have the most statistical significance in our analyses of teaching income. Domestic rankings which use multiple indicators have no such impact.

These findings are consistent with the fact that, in contemporary England, the fees which can vary between universities are mostly those paid by international students. Domestic reputational measures may affect home students' choices, but English undergraduate fees are effectively uniform across institutions. Future research might usefully examine whether domestic measures have more impact in countries with a more comprehensively deregulated sector. The current study was also unable to look at the value of a national brand. It is possible that all English universities benefit (and might in future suffer) from the national system's reputation overseas: again, this might usefully be studied.

While the results reported here reflect some England-specific circumstances, they also confirm that a global dynamic is giving both league tables and 'brand' enormous importance. We may conclude that universities are extremely unlikely to change their preoccupation with research excellence, at least in the short term: and that, as long as higher education remains an 
international enterprise, global 'winners' are likely both to retain their position and increase their wealth. Governments concerned to promote greater equality within the higher education sector, or to reduce the importance given to research, need to be aware that system dynamics are taking universities in the opposite direction.

End notes

1. See Jenkins and Wolf 2016 for full specification of this model

2. In other regressions not reported here, the presence of a medical school was not statistically significant in any models. We explored several growth variables, but none of them were statistically significant in models which controlled for other factors.

3 . The rankings have changed over time and now (2017) include more institutions. 4.22 of the 24 Russell Group universities were in the top 200 in THE world rankings in 2012/13; all of them were in this top 200 in 2015/16.

\section{Acknowledgments}

The authors wish to acknowledge the very helpful comments and suggests of the anonymous referees. 
References

Aldrich, R (ed, 2002), A Century of Education. RoutledgeFalmer: London.

Allison, P D (2009) Fixed Effects Regression Models Sage: London

Altbach, P (2004) The Costs and Benefits of World-Class Universities Academe 90.1 20-23

Altbach, P and Knight, J (2007), The Internationalization of Higher Education: Motivation and Realities', Journal of Studies in International Education, 11/3-4, 290-305.

Bastedo M \& Bowman N 2011 College Rankings as an Interorganizational Dependency: Establishing the Foundation for Strategic and Institutional Accounts Research in Higher Education 52 3-23

Bienkowski, A, Brada, J and Stanley G (eds) (2012) The University in the Age of Globalization: Rankings, Resources and Reforms Palgrave Macmillan: Basingstoke

Blackmore, P (2016), Prestige in Academic Life: Excellence and Exclusion. Routledge: Abingdon.

Bok, D 2003 Universities in the Marketplace Princeton University Press

Bourdieu, P 1989 La Noblesse d'Etat Paris: Edition de Minuit

Brown, R (2011) 'The march of the market' in Molesworth,M., Scullion, R. \& Nixon, E eds The Marketisation of Higher Education and the Student as Consumer Routledge: London 11-24

Chapleo C, Duran, M.V.C \& Diaz A.C 2011 Do UK universities communicate their brands effectively through their websites? Journal of Marketing for Higher Education 21.1 25-46

Dearden, L, Goodman, A, and Wyness, G (2012), 'Higher Education Finance in the UK.' Fiscal Studies, 33(1), 73-105.

Filappakou O \& Tapper T 2015 Mission Groups and the New Politics of British Higher Education Higher Education Quarterly 69.2 121-137

Finch , D, McDonald S \& Staple J 2013 Reputational interdependence: an examination of category reputation in higher education Journal of Marketing for Higher Education 23.1 34-61

Fowles J, Frederickson G \& Koppell J 2016 University Rankings: Evidence and a Conceptual Framework Public Administration Review 76.5

Frank R H and Cook P J (1995) The Winner-Take-All Society (Free Press)

Fumasoli, T. and Huisman, J. (2013) 'Strategic agency and system diversity: Conceptualizing institutional positioning in higher education.' Minerva, 51(2), 55-169. 
Gardberg N \& Fombrun C 2002The global reputation quotient project Corporate Reputation Review 4.4 303-307

Gibbons, S. Neumayer, E \& Perkins, R 2015 Student satisfaction, league tables and university applications: Evidence from Britain Economics of Education Review 48 148-164

Hazelkorn, E (2015), Rankings and the Reshaping of Higher Education: The Battle for World-Class Excellence, ( ${ }^{\text {nd }}$ Edition). Palgrave Macmillan: Basingstoke.

Hensley-Brown J \& Oplatka I 2006 Universities in a Competitive Global Marketplace. A systematic review of the literature on higher education marketing. International Journal of Public Sector Management 19.4 316-338

Jenkins A and Wolf A (2016) What's in a name? The effect of brand on UK universities' fee levels UCL: IOE Dept of Social Science, Working Paper 12

Jones, W. 2016 Do College Rankings Matter? Examining the Influence of “America's Best Black Colleges" on HBCU Undergraduate Admissions American Journal of Education 122.2 247-265

Kaufman, R. L. (2013) Heteroskedasticity in Regression. Sage: London.

Kaycheng, S (2015) 'Multicollinearity and Indicator Redundancy Problems in Wolrd University Rankings ' Higher Education Quarterly 69.2 158-174

Kim, J (2017) 'The Functions and Dysfunctions of College Rankings: An Analysis of Institutional Expenditure' Research in Higher Education DOI 10.1007/s11162-017-9455-1

Laidler-Kailander, N., Quelch, J.A. and Simonin, B.L. 2007 Building and Valuing Global brands in the Nonprofit Sector Nonprofit Management \& Leadership 17.3 253-77

Marginson, S (2014), 'University Rankings and Social Science.' European Journal of Education, 49(1), 45-59.

Marginson S 2016 The worldwide trend to high participation higher education: dynamics of social stratification in inclusive systems Higher Education 72(4) 413-34

McCutcheon S (2017) “World Insight” Times Higher Education 28 October

Molesworth, M., Scullion, R. \& Nixon, E eds 2011 The Marketisation of Higher Education and the Student as Consumer Routledge: London

Moodie, G. (2015) How Different are Higher Education Institutions in the UK, US and Australia? The Significance of Government Involvement Higher Education Quarterly 69.1 3-36

Morphew, C.C., Fumasoli, T. and Stensaker, B. (2016) Changing missions? How the strategic plans of research-intensive universities in Northern Europe and North America balance competing identities Studies in Higher Education 1-15 
Palfreyman D \& Tapper T 2014 Reshaping the University: the rise of the regulated market in higher education Oxford University Press

Pizarro Milian, R. (2017) What's for Sale at Canadian Universities? A Mixed-Methods Analysis of Promotional Strategies Higher Education Quarterly 71.1 53-74

Rosenzweig, P (2014) The Halo Effect Simon \& Schuster

Sauder M \& Lancaster R 2006 Do Rankings Matter? The Effects of U.S. News and World Report Rankings on the Admissions Process of Law Schools Law \& Society Review 40.1 105134

Wolf, A, (2002), Does Education Matter? Myths about Education and Economic Growth. Penguin: London.

Wolf, A (2016) Remaking Tertiary Education Education Policy Institute: London

Yudkevich, M., Altbacj, P and Rumbley, L (Eds) (2016) The Global Academic Rankings Game: Changing Policy, Practice and Academic Life Routledge 


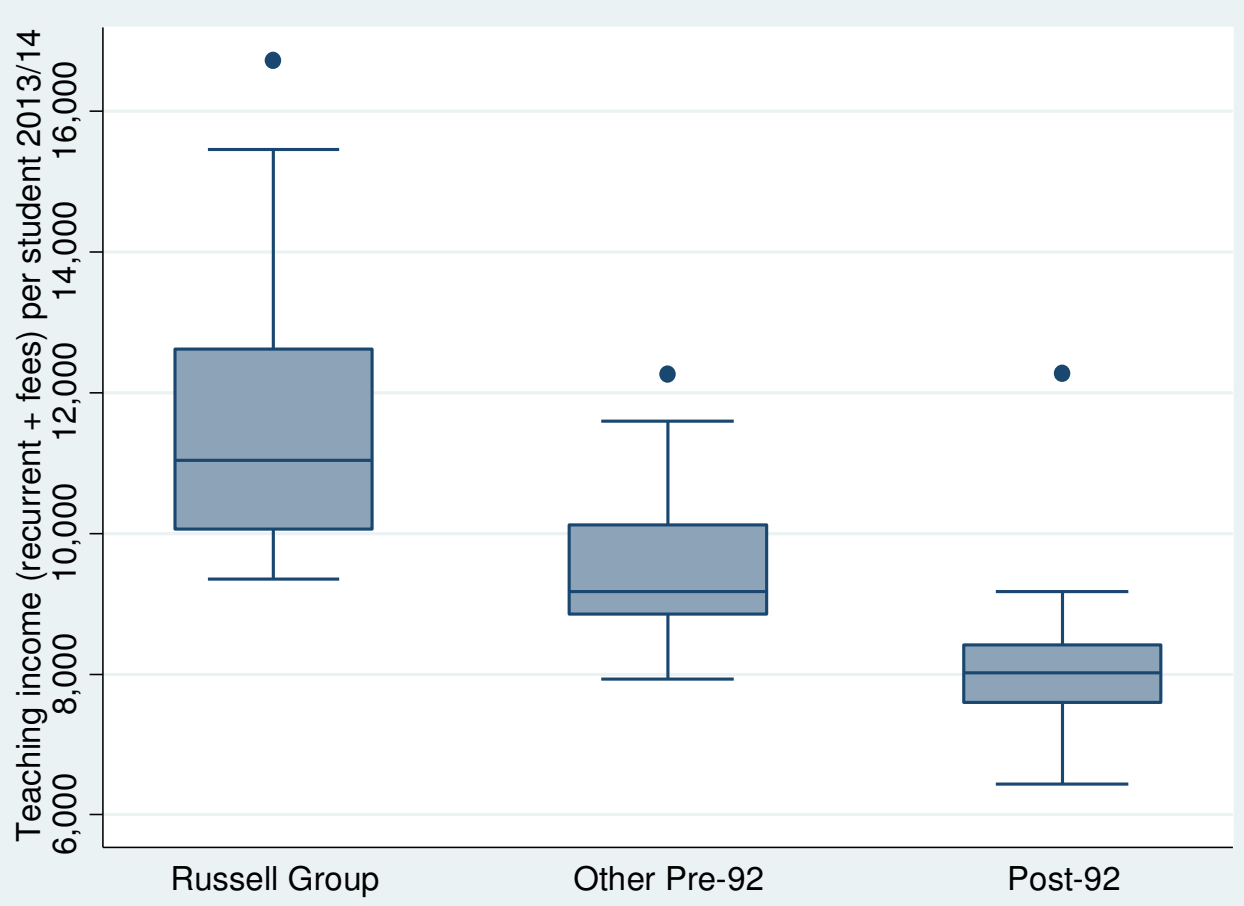

Figure 1: Teaching income (recurrent + fees) per FTE student 2013/14, English universities

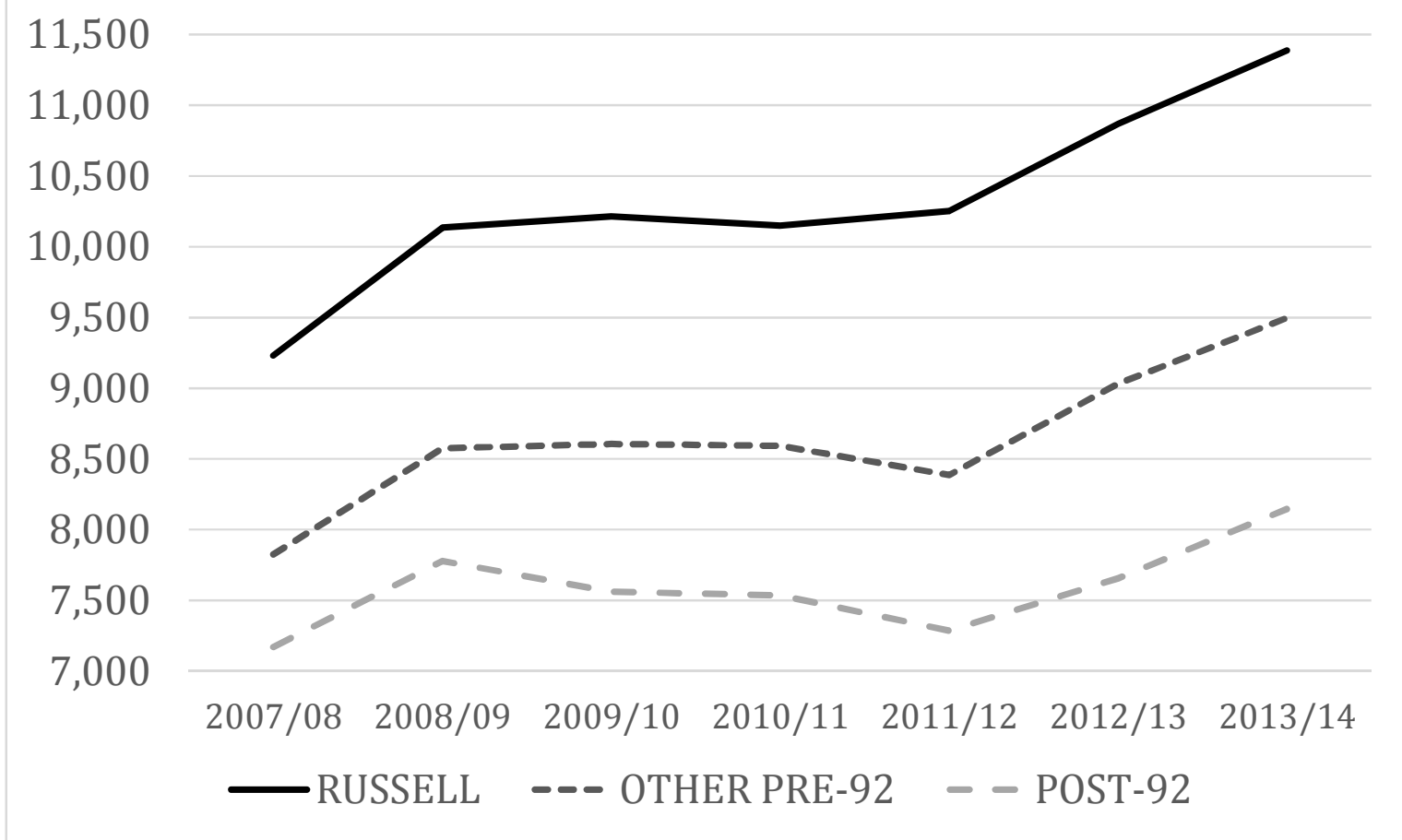

Figure 2: Real teaching income per student, $2007 / 08$ to $2013 / 14$, by sector.

English universities. $£, 2014$ prices. 


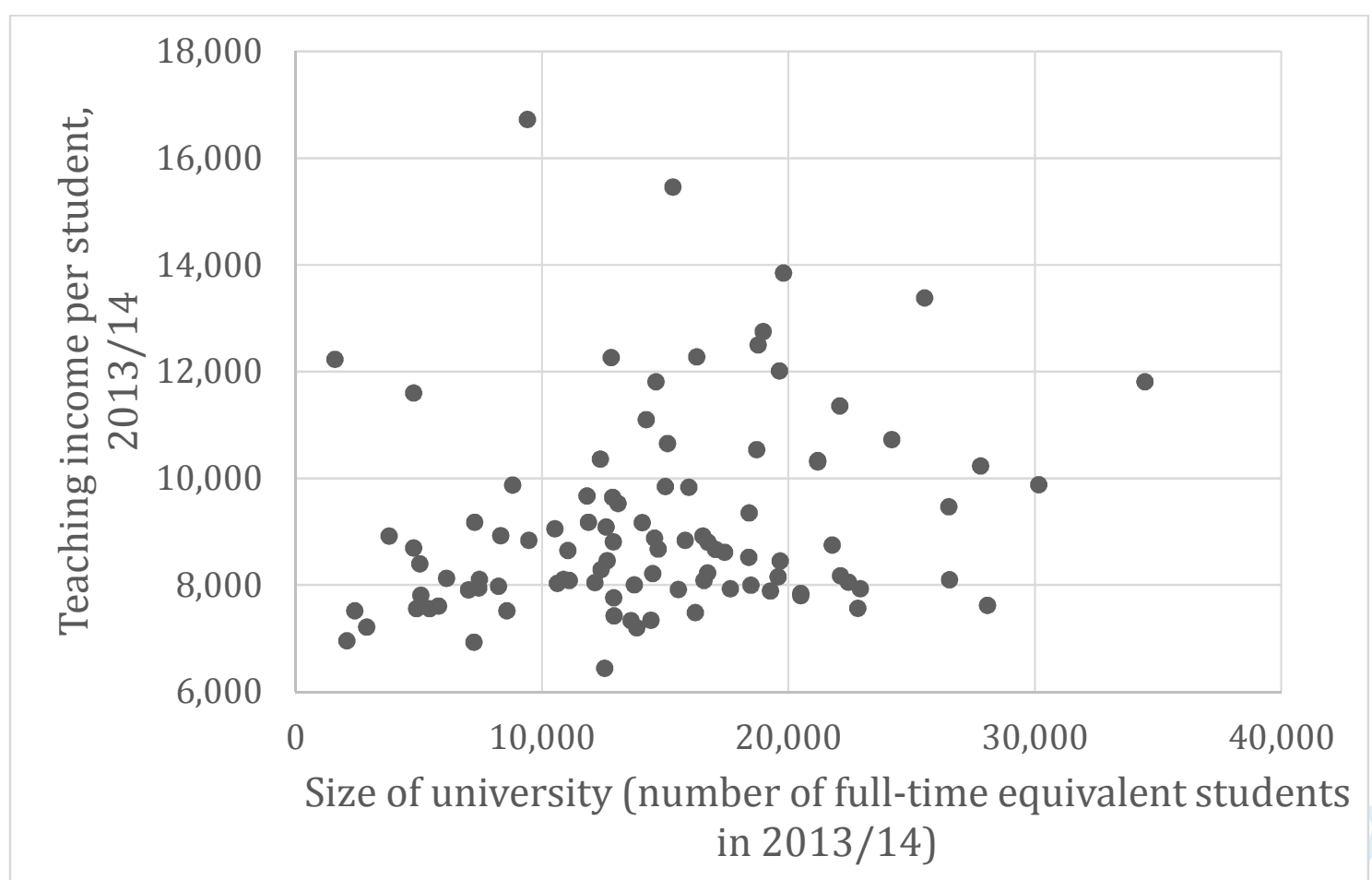

Figure 3: Teaching income per student and size of university (FTE students) 
Table 1: Regression models for teaching income per student, including UK-specific reputational indicators

\begin{tabular}{|c|c|c|c|c|c|}
\hline & $(1)$ & $(2)$ & $(3)$ & $(4)$ & (5) \\
\hline RAE ranking (2008) & $\begin{array}{c}-35.533^{* * * *} \\
(-8.41)\end{array}$ & $\begin{array}{c}-14.618^{* * *} \\
(-3.26)\end{array}$ & $\begin{array}{l}-9.239^{*} \\
(-2.27)\end{array}$ & $\begin{array}{l}-3.265 \\
(-0.65)\end{array}$ & $\begin{array}{l}-1.042 \\
(-0.22)\end{array}$ \\
\hline \multicolumn{6}{|c|}{ Type of university (reference: other pre-92 university) } \\
\hline Russell Group university & & $\begin{array}{c}1685.261^{* * * *} \\
(3.42)\end{array}$ & $\begin{array}{c}1817.316^{* * * *} \\
(4.15)\end{array}$ & & $\begin{array}{c}1603.159^{* * * *} \\
(5.06)\end{array}$ \\
\hline New university & & $-796.568^{*}$ & $\begin{array}{c}-966.214^{* * *} \\
(-3.02)\end{array}$ & & $\begin{array}{c}340.962 \\
(0.81)\end{array}$ \\
\hline London & & & $\begin{array}{c}1282.076^{* * * *} \\
(3.51)\end{array}$ & $\begin{array}{c}870.097^{* *} \\
(2.96)\end{array}$ & $\begin{array}{c}820.363^{* *} \\
(3.38)\end{array}$ \\
\hline Percentage STEM & & & & $\begin{array}{c}108.600^{* *} \\
(3.16)\end{array}$ & $\begin{array}{c}76.815^{*} \\
(2.52)\end{array}$ \\
\hline Proportion international & & & & $\begin{array}{c}107.942^{* * *} \\
(5.01)\end{array}$ & $\begin{array}{c}107.349^{* * * *} \\
(5.84)\end{array}$ \\
\hline University size & & & & $\begin{array}{l}-0.017 \\
(-1.12)\end{array}$ & $\begin{array}{l}-0.043^{*} \\
(-2.49)\end{array}$ \\
\hline Constant & $\begin{array}{c}11425.520^{* * * *} \\
(30.22)\end{array}$ & $\begin{array}{c}10142.984^{* * *} \\
(30.71)\end{array}$ & $\begin{array}{c}9609.724^{* * * *} \\
(33.41)\end{array}$ & $\begin{array}{c}7143.178^{* * *} \\
(10.61)\end{array}$ & $\begin{array}{c}7068.833^{\text {**** }} \\
(13.34)\end{array}$ \\
\hline Observations & 93 & 93 & 93 & 93 & 93 \\
\hline$R^{2}$ & 0.560 & 0.650 & 0.721 & 0.794 & 0.852 \\
\hline
\end{tabular}


Table 2: Further regression models for teaching income per student, including further UK-specific reputational indicators

\begin{tabular}{|c|c|c|c|c|}
\hline & $(1)$ & $(2)$ & (3) & $(4)$ \\
\hline NSS score & $\begin{array}{c}131.330^{* * * * *} \\
(3.49)\end{array}$ & $\begin{array}{c}-45.637 \\
(-1.92)\end{array}$ & & \\
\hline \multicolumn{5}{|c|}{ Type of university (reference: other pre-92 university) } \\
\hline Russell Group university & & $\begin{array}{c}1684.077^{* * *} \\
(5.36)\end{array}$ & & $\begin{array}{l}1546.818^{* * * *} \\
\quad(4.95)\end{array}$ \\
\hline New university & & $\begin{array}{c}171.351 \\
(0.52)\end{array}$ & & $\begin{array}{c}447.224 \\
(1.26)\end{array}$ \\
\hline Percentage STEM & & $\begin{array}{c}83.434^{* *} \\
(2.79)\end{array}$ & & $\begin{array}{c}56.043 \\
(1.69)\end{array}$ \\
\hline $\begin{array}{l}\text { Proportion international } \\
\text { (non-EU) students }\end{array}$ & & $\begin{array}{c}114.867^{* * *} \\
(7.58)\end{array}$ & & $\begin{array}{c}97.087^{* * *} \\
(5.23)\end{array}$ \\
\hline London & & $\begin{array}{c}682.205^{* *} \\
(2.98)\end{array}$ & & $\begin{array}{c}978.525^{* * *} \\
(4.20)\end{array}$ \\
\hline University size & & $\begin{array}{c}-0.053^{* * *} \\
(-3.79)\end{array}$ & & $\begin{array}{l}-0.039^{*} \\
(-2.47)\end{array}$ \\
\hline Guardian score 2012/13 & & & $\begin{array}{c}97.861^{* * *} \\
(8.17)\end{array}$ & $\begin{array}{c}21.611 \\
(1.72)\end{array}$ \\
\hline Constant & $\begin{array}{c}-1753.359 \\
(-0.56)\end{array}$ & $\begin{array}{c}10921.015^{* * *} \\
(5.22)\end{array}$ & $\begin{array}{c}3550.603^{* * *} \\
(5.61)\end{array}$ & $\begin{array}{l}5931.387^{* * * *} \\
\quad(8.77)\end{array}$ \\
\hline
\end{tabular}




\begin{tabular}{lcccc}
\hline Observations & 96 & 96 & 92 & 92 \\
$R^{2}$ & 0.135 & 0.852 & 0.556 & 0.853 \\
\hline${ }^{t}$ statistics in parentheses & & & & \\
${ }^{* * *} p<0.05,{ }^{* * * *} p<0.01,{ }^{*} p<0.001$ & & & &
\end{tabular}

Table 3: Further regression models for teaching income per student, including global reputational indicators

\begin{tabular}{|c|c|c|c|c|c|}
\hline \multicolumn{6}{|c|}{ (1) } \\
\hline \multicolumn{6}{|c|}{ Ranking (reference outside top 200, incl unranked) } \\
\hline Ranked in top 50 & $\begin{array}{c}5683.351^{* * * *} \\
(8.18)\end{array}$ & $\begin{array}{c}4340.242^{* * * *} \\
(5.19)\end{array}$ & $\begin{array}{c}2946.416^{* * * *} \\
(4.44)\end{array}$ & $\begin{array}{c}3520.688^{* * * *} \\
(7.93)\end{array}$ & $\begin{array}{c}2669.009^{* * * *} \\
(4.56)\end{array}$ \\
\hline Ranked in top 200 (but outside top 50) & $\begin{array}{c}2162.338^{* * *} \\
(9.39)\end{array}$ & $\begin{array}{c}930.222^{*} \\
(2.38)\end{array}$ & $\begin{array}{c}478.456 \\
(1.42)\end{array}$ & $\begin{array}{c}1070.228^{* * * *} \\
\quad(4.42)\end{array}$ & $\begin{array}{c}487.642 \\
(1.31)\end{array}$ \\
\hline \multicolumn{6}{|c|}{ Type of university (reference: other pre-92 university) } \\
\hline Russell Group university & & $\begin{array}{c}369.975 \\
(1.08)\end{array}$ & $\begin{array}{c}582.557 \\
(1.93)\end{array}$ & & $\begin{array}{c}868.767^{*} \\
(2.27)\end{array}$ \\
\hline Post-92 university & & $\begin{array}{c}-1216.417^{\text {*** }} \\
(-3.62)\end{array}$ & $\begin{array}{c}-131.446 \\
(-0.45)\end{array}$ & & $\begin{array}{c}41.032 \\
(0.13)\end{array}$ \\
\hline Proportion international & & & $\begin{array}{c}104.148^{* * *} \\
(5.85)\end{array}$ & $\begin{array}{c}90.816^{* * *} \\
(6.91)\end{array}$ & $\begin{array}{c}94.319^{* * * *} \\
(6.06)\end{array}$ \\
\hline Percentage STEM & & & & $\begin{array}{c}26.845 \\
(1.40)\end{array}$ & $\begin{array}{r}29.157 \\
(1.39)\end{array}$ \\
\hline
\end{tabular}




\begin{tabular}{|c|c|c|c|c|c|}
\hline London & & & & $\begin{array}{c}732.499^{* *} \\
(3.31)\end{array}$ & $\begin{array}{c}706.824^{* * * *} \\
(3.47)\end{array}$ \\
\hline University size & & & & $\begin{array}{l}-0.026^{*} \\
(-2.40)\end{array}$ & $\begin{array}{c}-0.036^{* * *} \\
(-3.13)\end{array}$ \\
\hline Constant & $\begin{array}{c}8312.637^{\text {*** }} \\
(68.35) \\
\end{array}$ & $\begin{array}{c}9285.770^{* * *} \\
(29.16) \\
\end{array}$ & $\begin{array}{c}7320.382^{\text {**** }} \\
(20.53)\end{array}$ & $\begin{array}{c}7460.157^{* * *} \\
(42.17)\end{array}$ & $\begin{array}{c}7516.592^{* * * *} \\
(21.31)\end{array}$ \\
\hline Observations & 96 & 96 & 96 & 96 & 96 \\
\hline$R^{2}$ & 0.689 & 0.742 & 0.863 & 0.888 & 0.896 \\
\hline
\end{tabular}


Table 4: Growth in real teaching income per student, 2007/08 to 2013/14

\begin{tabular}{|c|c|c|c|c|c|}
\hline & (1) & (2) & (3) & (4) & (5) \\
\hline \multirow{2}{*}{$\begin{array}{l}\text { Change in ranking group } \\
2007 / 08 \text { to } 2011 / 12(+v e \\
=\text { improved ranking) }\end{array}$} & 1.3430 & 3.6661 & $4.7557^{*}$ & $4.2804^{*}$ & $4.2131^{*}$ \\
\hline & $(0.50)$ & $(1.93)$ & $(2.58)$ & (1.99) & $(2.27)$ \\
\hline Russell Group university & & $\begin{array}{c}2.6041 \\
(1.01)\end{array}$ & $\begin{array}{c}-0.6208 \\
(-0.22)\end{array}$ & & $\begin{array}{c}-3.3719 \\
(-1.11)\end{array}$ \\
\hline New university & & $\begin{array}{c}-9.1224^{* * *} \\
(-3.82)\end{array}$ & $\begin{array}{c}-10.0191^{* * * *} \\
(-4.27)\end{array}$ & & $\begin{array}{c}-7.3990^{*} \\
(-2.28)\end{array}$ \\
\hline University size & & & $\begin{array}{c}0.0005^{* *} \\
(2.80)\end{array}$ & $\begin{array}{c}0.0003 \\
(1.84)\end{array}$ & $\begin{array}{c}0.0004^{*} \\
(2.39)\end{array}$ \\
\hline Percent STEM & & & & $\begin{array}{c}5.9082^{* * *} \\
(3.38)\end{array}$ & $\begin{array}{c}3.9396 \\
(1.67)\end{array}$ \\
\hline Percent non-EU & & & & $\begin{array}{l}0.1572 \\
(1.14)\end{array}$ & $\begin{array}{c}0.0066 \\
(0.04)\end{array}$ \\
\hline Constant & $\begin{array}{c}16.7117^{* * * *} \\
(14.50)\end{array}$ & $\begin{array}{c}21.5873^{\text {*** }} \\
(11.35)\end{array}$ & $\begin{array}{c}16.0338^{* * *} \\
(6.05)\end{array}$ & $\begin{array}{c}6.0731^{*} \\
(2.43)\end{array}$ & $\begin{array}{c}12.7570^{* * *} \\
(3.04)\end{array}$ \\
\hline Observations & 96 & 96 & 96 & 96 & 96 \\
\hline$R^{2}$ & 0.002 & 0.223 & 0.293 & 0.271 & 0.314 \\
\hline
\end{tabular}

$t$ statistics in parentheses

- $p<0.05,{ }^{* * *} p<0.01,{ }^{* * *} p<0.00$ 
- Table 5: Fixed effects regression for real teaching income per student, 2007/08 to 2013/14

\begin{tabular}{|c|c|c|c|c|c|}
\hline & $(1)$ & $(2)$ & (3) & $(4)$ & $(5)$ \\
\hline \multicolumn{6}{|l|}{ THE ranking (base: not in top 200) } \\
\hline THE ranking: top 50 & $\begin{array}{r}-55.09 \\
(-025)\end{array}$ & $\begin{array}{l}48.43 \\
(0.32)\end{array}$ & $\begin{array}{r}103.70 \\
(0.69)\end{array}$ & $\begin{array}{r}127.54 \\
(084)\end{array}$ & $\begin{array}{r}101.18 \\
(072)\end{array}$ \\
\hline THE ranking : 51 to 100 & $\begin{array}{l}-247.22 \\
(-1.64)\end{array}$ & $\begin{array}{c}-177.95 \\
(-1.68)\end{array}$ & $\begin{array}{c}-176.73 \\
(-1.69)\end{array}$ & $\begin{array}{c}-159.09 \\
(-1.50)\end{array}$ & $\begin{array}{c}-191.31 \\
(-1.96)\end{array}$ \\
\hline THE ranking: 101 to 150 & $\begin{array}{c}-491.27^{* *} \\
(-3.26)\end{array}$ & $\begin{array}{c}-328.69^{* * *} \\
(-3.09)\end{array}$ & $\begin{array}{c}-261.31^{*} \\
(-2.45)\end{array}$ & $\begin{array}{c}-231.52^{*} \\
(-2.10)\end{array}$ & $\begin{array}{l}-134.15 \\
(-1.32)\end{array}$ \\
\hline THE ranking: 151 to 200 & $\begin{array}{c}-208.85 \\
(-1.50)\end{array}$ & $\begin{array}{r}-241.53^{*} \\
(-2.46)\end{array}$ & $\begin{array}{c}-197.78^{*} \\
(-2.03)\end{array}$ & $\begin{array}{c}-178.96 \\
(-1.81)\end{array}$ & $\begin{array}{l}-103.24 \\
(-1.13)\end{array}$ \\
\hline \multirow{2}{*}{$\begin{array}{l}\text { Interaction: top } 50 \text { ranking /post } \\
2009\end{array}$} & $922.38^{* * * *}$ & $800.86^{* * *}$ & $748.86^{* * * *}$ & $720.89^{* * * *}$ & $766.42^{* * *}$ \\
\hline & $(8.00)$ & $(9.58)$ & $(8.95)$ & $(8.24)$ & $(9.49)$ \\
\hline \multirow{2}{*}{$\begin{array}{l}\text { Interaction: ranking } 51 \text { to } 100 / \text { post } \\
2009\end{array}$} & $488.53^{* *}$ & $475.81^{* * *}$ & $463.53^{* * *}$ & $452.88^{* * *}$ & $495.82^{* * *}$ \\
\hline & $(3.29)$ & $(4.46)$ & $(4.39)$ & $(4.27)$ & $(5.07)$ \\
\hline \multirow[t]{2}{*}{$\begin{array}{l}\text { Interaction: ranking } 101 \text { to } 150 \\
\text { /post } 2009\end{array}$} & $762.48^{* * * *}$ & $546.71^{* * * *}$ & $419.66^{* * *}$ & $384.37^{\text {**** }}$ & $288.19^{* * *}$ \\
\hline & $(5.69)$ & $(5.63)$ & $(4.14)$ & $(3.61)$ & $(2.92)$ \\
\hline \multirow{2}{*}{$\begin{array}{l}\text { Interaction: ranking } 151 \text { to } 200 \\
\text { /post } 2009\end{array}$} & $608.16^{* * * *}$ & $531.44^{* * * *}$ & $412.01^{* * * *}$ & $385.84^{\text {**** }}$ & $317.66^{* * *}$ \\
\hline & $(4.64)$ & $(5.60)$ & $(4.17)$ & $(3.80)$ & $(3.38)$ \\
\hline \multicolumn{6}{|l|}{ Year dummies (base, 2007) } \\
\hline \multicolumn{2}{|l|}{2008} & $\begin{array}{c}489.24^{* * *} \\
(13.51)\end{array}$ & $\begin{array}{c}478.58^{* * * *} \\
(13.34)\end{array}$ & $\begin{array}{c}475.47^{* * * *} \\
(13.22)\end{array}$ & $\begin{array}{r}514.84^{* * *} \\
(15.42)\end{array}$ \\
\hline \multirow[t]{2}{*}{2009} & & $\begin{array}{c}435.79^{* * *} \\
(12.02)\end{array}$ & $\begin{array}{c}410.74^{* * *} \\
(11.29)\end{array}$ & $\begin{array}{l}404.27^{* * *} \\
(10.97)\end{array}$ & $\begin{array}{r}516.75^{* * *} \\
(14.44)\end{array}$ \\
\hline & & $261.73^{* * *}$ & $240.16^{* * * *}$ & $234.45^{* * *}$ & $335.44^{* * *}$ \\
\hline
\end{tabular}


2011

$\begin{array}{cccc}(6.87)^{* * *} & (6.31) & (6.11) & (9.12) \\ 127.65^{* * *} & 107.64^{* *} & 98.86^{*} & 231.17^{* * *} \\ (3.35)^{* * *} & (2.83) & (2.54)^{* * *} & (6.05)^{* * *} \\ 451.62^{* *} & 422.22^{* * *} & 414.14^{* * *} & 467.24^{* * *} \\ (11.83)^{* * *} & (10.97)^{* *} & (10.57) & (12.80) \\ 782.62^{* * * *} & 739.80^{* * *} & 729.40^{* * *} & 751.70^{* * *} \\ (20.53) & (18.84) & (18.06) & (20.15)\end{array}$

Percent Non-EU

$21.01^{* * *} \quad 19.98^{* * *} \quad 43.91^{* * *}$

(3.86) (3.62) $\quad$ (7.80)

Percent STEM

$94.54 \quad 267.29^{* *}$

(1.10) (3.28)

University size

$-0.13^{* * * *}$

$(-10.01)$

\begin{tabular}{|c|c|c|c|c|c|}
\hline Constant & $\begin{array}{c}6022.99^{* * * *} \\
(173.52)\end{array}$ & $\begin{array}{c}5656.14^{* * * *} \\
(161.71)\end{array}$ & $\begin{array}{c}5413.91^{* * *} \\
(75.54)\end{array}$ & $\begin{array}{c}5345.07^{* * *} \\
(56.08)\end{array}$ & $\begin{array}{c}6651.12^{* * * *} \\
(42.27)\end{array}$ \\
\hline Observations & 672 & 672 & 672 & 672 & 672 \\
\hline Number of universities & 96 & 96 & 96 & 96 & 96 \\
\hline $\mathrm{R}^{2}$ between & 0.482 & 0.498 & 0.781 & 0.777 & 0.223 \\
\hline $\mathrm{R}^{2}$ within & 0.219 & 0.625 & 0.634 & 0.635 & 0.690 \\
\hline $\mathrm{R}^{2}$ overall & 0.226 & 0.226 & 0.531 & 0.591 & 0.260 \\
\hline
\end{tabular}


6670 words including abstract and references but excluding Table 1A (below, for Appendix) 
Table 1A List of universities included in the analysis

$\begin{array}{rlll}\text { Count } & \text { Institution } & \text { type } & \text { location } \\ 1 & \text { The University of Bristol } & \text { Russell Group } & \text { England } \\ 2 & \text { The University of Nottingham } & \text { Russell Group } & \text { England } \\ 3 & \text { The University of Oxford } & \text { Russell Group } & \text { England } \\ 4 & \text { The University of Durham } & \text { Russell Group } & \text { England } \\ 5 & \text { The University of Leeds } & \text { Russell Group } & \text { England } \\ & \text { University of Newcastle-upon- } & & \\ 6 & \text { Tyne } & \text { Russell Group } & \text { England } \\ 7 & \text { Queen Mary University of London } & \text { Russell Group } & \text { England } \\ 8 & \text { The University of Cambridge } & \text { Russell Group } & \text { England } \\ 9 & \text { LSE (London School of Economics) } & \text { Russell Group } & \text { England } \\ 10 & \text { The University of Southampton } & \text { Russell Group } & \text { England } \\ 11 & \text { King's College London } & \text { Russell Group } & \text { England } \\ 12 & \text { University of Manchester } & \text { Russell Group } & \text { England } \\ 13 & \text { Imperial College } & \text { Russell Group } & \text { England } \\ 14 & \text { The University of Sheffield } & \text { Russell Group } & \text { England } \\ 15 & \text { The University of Liverpool } & \text { Russell Group } & \text { England } \\ 16 & \text { The University of Exeter } & \text { Russell Group } & \text { England } \\ 17 & \text { The University of Birmingham } & \text { Russell Group } & \text { England } \\ 18 & \text { The University of York } & \text { Russell Group } & \text { England } \\ 19 & \text { University of Warwick } & \text { Russell Group } & \text { England } \\ 20 & \text { University College London } & \text { Russell Group } & \text { England } \\ 21 & \text { The University of Sussex } & \text { Other pre-92 } & \text { England } \\ 22 & \text { The University of Salford } & \text { Other pre-92 } & \text { England } \\ 23 & \text { SOAS } & \text { Other pre-92 } & \text { England } \\ 24 & \text { Royal Holloway } & \text { Other pre-92 } & \text { England }\end{array}$


25 The University of Essex

26 The University of Bradford

27 The University of Bath

28 Goldsmiths College

29 The University of East Anglia

30 The University of Reading

31 The University of Hull

32 The University of Leicester

33 The University of Lancaster

34 Aston University

35 The University of Surrey

36 The University of Kent

37 Loughborough University

38 The City University

39 Brunel University London

40 The University of Keele

41 Oxford Brookes University

42 Manchester Met

43 Birmingham City University

44 Coventry University

45 Teesside University

46 The University of Portsmouth

47 The University of Sunderland

48 The University of West London

49 UWE

50 The University of East London

51 Sheffield Hallam University
Other pre-92

Other pre-92

Other pre-92

Other pre-92

Other pre-92

Other pre-92

Other pre-92

Other pre-92

Other pre-92

Other pre-92

Other pre-92

Other pre-92

Other pre-92

Other pre-92

Other pre-92

Other pre-92

Former polytechnic

Former polytechnic

Former polytechnic

Former polytechnic

Former polytechnic

Former polytechnic

Former polytechnic

Former polytechnic

Former polytechnic

Former polytechnic

Former polytechnic
England

England

England

England

England

England

England

England

England

England

England

England

England

England

England

England

England

England

England

England

England

England

England

England

England

England

England 
52 The University of Lincoln

53 University of Hertfordshire

54 University of Plymouth

55 The University of Huddersfield

56 The University of Greenwich

57 Bournemouth University

58 Leeds Beckett University

59 London Metropolitan University

60 London South Bank University

61 Staffordshire University The University of Central

62 Lancashire

63 University of Westminster

64 De Montfort University

65 Liverpool John Moores University

66 The Nottingham Trent University

67 University of Northumbria

68 University of Wolverhampton

69 Kingston University

70 The University of Brighton

71 Anglia Ruskin University

72 Middlesex University

73 York St John University

74 University of Worcester

75 Bishop Grosseteste University

76 University of Bedfordshire

77 University of Gloucestershire
Former polytechnic Former polytechnic Former polytechnic Former polytechnic Former polytechnic Former polytechnic Former polytechnic Former polytechnic Former polytechnic Former polytechnic

Former polytechnic Former polytechnic Former polytechnic Former polytechnic Former polytechnic Former polytechnic Former polytechnic Former polytechnic Former polytechnic Former polytechnic Former polytechnic Other post-92 Other post-92 Other post-92 Other post-92 Other post-92
England

England

England

England

England

England

England

England

England

England

England

England

England

England

England

England

England

England

England

England

England

England

England

England

England

England 
78 University of Winchester

79 The University of Northampton

80 Falmouth University

81 University for the Creative Arts

82 University of Derby

83 Buckinghamshire New University

84 Southampton Solent University

85 Newman University

86 Leeds Trinity University

87 University of the Arts, London Canterbury Christ Church

88 University

89 University of Cumbria

90 Edge Hill University

91 The University of Bolton

92 University of Chester

93 The University of Chichester

94 Bath Spa University

95 Roehampton University

96 Liverpool Hope University

97 The University of Buckingham
Other post-92

Other post-92

Other post-92

Other post-92

Other post-92

Other post-92

Other post-92

Other post-92

Other post-92

Other post-92

Other post-92

Other post-92

Other post-92

Other post-92

Other post-92

Other post-92

Other post-92

Other post-92

Other post-92

Private
England

England

England

England

England

England

England

England

England

England

England

England

England

England

England

England

England

England

England

England 